OPEN ACCESS

Edited by:

Manuel Kleiner,

University of Calgary, Canada

Reviewed by:

Jeffrey A. Lewis,

University of Arkansas, USA

Karsten Tedin

Freie Universität Berlin, Germany

*Correspondence:

Thilo M. Fuchs

thilo.fuchs@wzw.tum.de

Specialty section:

This article was submitted to

Microbial Physiology and Metabolism,

a section of the journal

Frontiers in Microbiology

Received: 13 July 2015

Accepted: 28 September 2015

Published: 12 October 2015

Citation:

Staib L and Fuchs TM (2015)

Regulation of fucose

and 1,2-propanediol utilization by

Salmonella enterica serovar

Typhimurium

Front. Microbiol. 6:1116

doi: 10.3389/fmicb.2015.01116

\section{Regulation of fucose and 1,2-propanediol utilization by Salmonella enterica serovar Typhimurium}

\author{
Lena Staib and Thilo M. Fuchs* \\ Lehrstuhl für Mikrobielle Ökologie, Zentralinstitut für Ernährungs- und Lebensmittelforschung Institute for Food and Health, \\ Technische Universität München, Freising, Germany
}

After ingestion, Salmonella enterica serovar Typhimurium (S. Typhimurium) encounters a densely populated, competitive environment in the gastrointestinal tract. To escape nutrient limitation caused by the intestinal microbiota, this pathogen has acquired specific metabolic traits to use compounds that are not metabolized by the commensal bacteria. For example, the utilization of 1,2-propanediol (1,2-PD), a product of the fermentation of L-fucose, which is present in foods of herbal origin and is also a terminal sugar of gut mucins. Under anaerobic conditions and in the presence of tetrathionate, 1,2-PD can serve as an energy source for $S$. Typhimurium. Comprehensive database analysis revealed that the 1,2-PD and fucose utilization operons are present in all $S$. enterica serovars sequenced thus far. The operon, consisting of 21 genes, is expressed as a single polycistronic mRNA. As demonstrated here, 1,2-PD was formed and further used when S. Typhimurium strain 14028 was grown with L-fucose, and the gene fucA encoding L-fuculose-1-phosphate aldolase was required for this growth. Using promoter fusions, we monitored the expression of the propanediol utilization operon that was induced at very low concentrations of 1,2-PD and was inhibited by the presence of D-glucose.

\section{Keywords: propanediol, Salmonella enterica serovar Typhimurium, metabolism, fucose, anaerobic growth}

\section{INTRODUCTION}

Members of the genus Salmonella are globally distributed and comprise 2,500 serovars described thus far. They infect cold- and warm-blooded animals as well as humans, and their transmission generally follows the fecal-oral route by consumption of contaminated foods, mostly of animal source. In Germany, salmonellosis (non-typhoidal Salmonella gastroenteritis) is the second most common form of bacterial gastroenteritis, with 18,986 reported cases in 2013 and an estimated 80-90\% unreported cases (Koch-Institut, 2014). In Europe, 91,034 salmonellosis cases were reported in 2012 (European Centre for Disease Prevention and Control, 2014). In the USA, Salmonella causes an estimated one million illnesses annually (Centres for Disease Control and Prevention, 2013). A major concern for public health is the emergence of Salmonella strains resistant to antimicrobials (Majowicz et al., 2010).

Salmonella enterica serovar Typhimurium (S. Typhimurium) causes non-typhoidal gastroenteritis in humans and typhoid-like disease in mice (Tsolis et al., 1999; Zhang et al., 2003). Expression of genes located on the so-called Salmonella pathogenicity islands (SPI) 1 and 2 are 
important during infection by enabling the invasion of epithelial cells and the intracellular replication and survival of S. Typhimurium (Galan and Ginocchio, 1994; Ochman et al., 1996). The acquisition of nutrients within the infected host is crucial for enteric pathogens, because they need energy as well as carbon and nitrogen sources in order to grow within host compartments, to compete against commensals, to colonize the epithelium, to produce virulence factors, to withstand the hosts's immune responses, and to transmit themselves to other hosts or the environment (Staib and Fuchs, 2014). As revealed previously, more than 60 compounds can serve as substrates for S. Typhimurium (Gutnick et al., 1969). However, it remains obscure which substrates are available or used during multiplication in the intestinal lumen and subsequent infection. Many enteric pathogens are equipped with specific metabolic pathways that play predominantly a role during infection to overcome nutrient limitations imposed by the host (Fuchs et al., 2012; Abu Kwaik and Bumann, 2013). Examples in $S$. Typhimurium are the gene clusters responsible for sialic acid, myo-inositol, and ethanolamine utilization (Staib and Fuchs, 2014). Proliferation of S. Typhimurium was impaired in gnotobiotic mice by a lack of sialic acids due to co-colonization with a sialidase-deficient Bacteroides thetaiotaomicron strain (Ng et al., 2013). The iol genes responsible for the degradation of myo-inositol (Kröger and Fuchs, 2009; Kröger et al., 2011; Rothhardt et al., 2014) are thought to contribute to the virulence of $S$. Typhimurium in mice, pigs, chickens, and calves (Lawley et al., 2006; Carnell et al., 2007; Chaudhuri et al., 2009, 2013). Growth attenuation has been reported in food, nematodes, and mice for $S$. Typhimurium deficient in ethanolamine utilization (Stojiljkovic et al., 1995; Srikumar and Fuchs, 2011; Thiennimitr et al., 2011). Recently, it was shown that tetrathionate is formed in the inflamed intestine from the reaction of reactive oxygen species (ROS) and sulfur compounds such as thiosulfate, a finding that linked anaerobic respiration and ethanolamine degradation with $S$. Typhimurium proliferation in the gut (Winter et al., 2010). Analysis of in vivo-induced genes and competitive index studies identified the capability of $S$. Typhimurium to degrade 1,2-propanediol (1,2PD) relevant for infection (Conner et al., 1998). This result was confirmed by the findings that propanediol utilization $(p d u)$ genes responsible for 1,2-PD are induced in murine and human cells, and that a lack of $p d u$ genes results in reduced replication in macrophages (Heithoff et al., 1999; Klumpp and Fuchs, 2007).

Salmonella enterica serovar Typhimurium is also capable of producing cobalamin (vitamin $\mathrm{B}_{12}$ ) under anaerobic conditions (Roth et al., 1996). The cob/cbi operon, responsible for de novo synthesis of cobalamin, and the $p d u$ operon comprising 23 genes encoding enzymes and a polyhedral body, are located side by side on the genome of $S$. Typhimurium (Jeter, 1990; Bobik et al., 1999). The expression of both operons is positively regulated by PocR and by two global regulators, namely the cAMP receptor protein (CRP) and $\mathrm{ArcA} / \mathrm{ArcB}$ for anoxic respiratory control (Bobik et al., 1992; Rondon and Escalante-Semerena, 1996; Ailion and Roth, 1997). Indeed, cobalamin plays a role in 1,2-PD degradation by $S$. Typhimurium as it is a cofactor of propanediol dehydratase, the first enzyme of this catabolic pathway (Chen et al., 1994; Bobik et al., 1997; Walter et al., 1997). 1,2-PD can serve as a carbon and energy source for Clostridium glycolicum and Klebsiella pneumoniae in a cobalamin-dependent manner under anaerobic conditions (Gaston and Stadtman, 1963; Toraya et al., 1979). S. Typhimurium was able to grow with 1,2-PD in the presence of this vitamin under aerobic conditions (Jeter, 1990). Growth of S. Typhimurium with 1,2$\mathrm{PD}$ in the absence of oxygen, however, was observed only when tetrathionate, which serves as a terminal electron acceptor for anaerobic respiration of $1,2-\mathrm{PD}$, was added to the medium (Price-Carter et al., 2001). 1,2-PD is the fermentation endproduct of bacterial growth with L-fucose and/or L-rhamnose (Daniel et al., 1998). While Escherichia coli is unable to further metabolize 1,2-PD when kept under anaerobic conditions, this compound vanishes from the $S$. Typhimurium culture medium suggesting its further utilization by this pathogen (Obradors et al., 1988).

The two sugars L-fucose and L-rhamnose are frequently found in the carbohydrate moieties of mucosal glycoconjugates, herbal cell walls, and bacterial exopolysaccharides (Sampson and Bobik, 2008). L-fucose, comprising $4-14 \%$ of the oligosaccharide content of mucins, is found mainly as a terminal sugar of the oligosaccharide chains linked to the mucin protein backbone (Muraoka and Zhang, 2011). Thus, mucus is the main source of gastrointestinal L-fucose provided by the enzymatic activities of Bacteroides (Keeney and Finlay, 2013). Degradation of L-fucose monomers is not restricted to commensal bacteria such as Bacteroides. The genetic determinants for L-fucose utilization are also found in the genomes of many enteropathogens (Staib and Fuchs, 2014), although to date, experimental confirmation of fucose utilization is largely lacking. Fermentation of L-fucose and subsequent 1,2-PD secretion have been described for E. coli (Cocks et al., 1974), K. pneumoniae, and S. Typhimurium (Badia et al., 1985). More recently, proteomic and glycomic evidence has been provided that $S$. Typhimurium takes advantage of fucose metabolization while growing in the mouse gut (Deatherage Kaiser et al., 2013).

In this study, we investigated genetic determinants of $S$. Typhimurium with a role in the utilization of mucus-derived sugar components. We determined the distribution of $p d u$ and fuc genes among salmonellae, and monitored promoter activities of both operons during all growth phases using luciferase reporter fusions. The results suggest a role of fucose and 1,2-PD utilization by $S$. Typhimurium in the environment and during infection.

\section{MATERIALS AND METHODS}

\section{Bacterial Strains, Plasmids, and Growth Conditions}

Bacterial strains and plasmids used in this study are listed in Table 1. S. Typhimurium and E. coli strains were grown at $37^{\circ} \mathrm{C}$ in lysogeny broth (LB) medium (10 g/l tryptone, $5 \mathrm{~g} / \mathrm{l}$ yeast extract, and $5 \mathrm{~g} / \mathrm{l} \mathrm{NaCl}$ ) or on LB-agar (LB-medium supplemented with $1.5 \%[\mathrm{w} / \mathrm{v}]$ agar). Liquid cultures were inoculated using a single colony or a 1:1,000 dilution of an overnight culture, and shaken 
TABLE 1 | Strains and plasmids used in the study.

\begin{tabular}{|c|c|c|}
\hline Strain & $\begin{array}{l}\text { Relevant genotype or } \\
\text { characteristics }\end{array}$ & Reference \\
\hline \multicolumn{3}{|c|}{ Salmonella enterica serovar Typhimurium (S. Typhimurium) } \\
\hline $14028\left(\mathrm{Nal}^{\mathrm{R}}\right)$ & $\begin{array}{l}\text { Spontaneous mutation of strain } \\
\text { ATCC } 14028 \text { on nalidixic acid }\end{array}$ & This study \\
\hline $14028 P_{\text {pduA }}:: / u x$ & $\begin{array}{l}\text { Genomic integration of pUTs } \\
l u x-C m^{R} \text { in } \mathrm{Nal}^{\mathrm{R}} \text { background }\end{array}$ & This study \\
\hline $14028 \mathrm{P}_{\text {fuco }}:: / \mathrm{l} x$ & $\begin{array}{l}\text { Genomic integration of } \\
\text { pUTs-lux-Cm }{ }^{R} \text { in } \mathrm{Nal}^{\mathrm{R}} \\
\text { background }\end{array}$ & This study \\
\hline $14028 \Delta p d u C$ & $\begin{array}{l}\text { Deletion of } p d u C \text { in } \mathrm{Nal}^{\mathrm{R}} \\
\text { background }\end{array}$ & This study \\
\hline $14028 \Delta f u c A:: k a n R$ & $\begin{array}{l}\mathrm{Kan}^{\mathrm{R}} \text { insertion mutant in place } \\
\text { of fucA }\end{array}$ & This study \\
\hline \multicolumn{3}{|l|}{ Escherichia coli } \\
\hline S17.1 $\lambda$ pir & $\begin{array}{l}\lambda \text {-pir lysogen of } \mathrm{S} 17.1\left(\mathrm{Tp}^{\mathrm{R}} \text {, }\right. \\
\text { Strept }^{\mathrm{R}}, \mathrm{Spec}^{\mathrm{R}} \text { thi pro } \\
\text { hsdR }^{-} \mathrm{M}^{+} \text {recA RP4::2-Tc::Mu } \\
\text { Km::Tn17) }\end{array}$ & Simon et al., 1983 \\
\hline
\end{tabular}

\begin{tabular}{|c|c|c|}
\hline \multicolumn{3}{|l|}{ Plasmids } \\
\hline pUTs-lux $\left(\mathrm{Cm}^{\mathrm{R}}\right)$ & $\begin{array}{l}\text { Suicide vector, promoterless } \\
\text { luxCDABE genes, R6K ori, oriT } \\
\text { (RP4); } \mathrm{Cm}^{\mathrm{R}}\end{array}$ & Starke et al., 2013 \\
\hline pUTs-gfp $\left(\mathrm{Cm}^{\mathrm{R}}\right)$ & $\begin{array}{l}\text { As above, promoterless gfp, } \\
\text { R6K ori, oriT (RP4); } \mathrm{Cm}^{\mathrm{R}}\end{array}$ & Starke et al., 2013 \\
\hline pKD46 & $\begin{array}{l}\lambda \text { Red recombinase expression } \\
\text { plasmid, oriR101/repA101(ts), } \\
\text { and } P_{\text {araB-gam-bet-exo, Amp }}\end{array}$ & $\begin{array}{l}\text { Datsenko and } \\
\text { Wanner, } 2000\end{array}$ \\
\hline pKD4 & $\begin{array}{l}\text { pir-dependent, FRT-recognition } \\
\text { sites; } \operatorname{Kan}^{\mathrm{R}}\end{array}$ & $\begin{array}{l}\text { Datsenko and } \\
\text { Wanner, } 2000\end{array}$ \\
\hline pCP20 & $\begin{array}{l}\text { FLP-recombinase plasmid; } \\
\mathrm{Cm}^{\mathrm{R}}, \mathrm{Amp}^{\mathrm{R}}\end{array}$ & $\begin{array}{l}\text { Datsenko and } \\
\text { Wanner, } 2000\end{array}$ \\
\hline pBR322 & Cloning vector; $\mathrm{Amp}^{\mathrm{R}}, \mathrm{Tet}^{\mathrm{R}}$ & Bolivar et al., 1977 \\
\hline pGreenTIR & $\begin{array}{l}\text { GFP-cloning vector, translation } \\
\text { initiation region (TIR), } \\
\mathrm{P}_{\text {lac-TIR-gfp; } \mathrm{Amp}^{\mathrm{R}}}\end{array}$ & $\begin{array}{l}\text { Miller and Lindow, } \\
1997\end{array}$ \\
\hline $\begin{array}{l}\text { pUTs-P pduA ::/ux } \\
\left(\mathrm{Cm}^{\mathrm{R}}\right)\end{array}$ & $\begin{array}{l}\text { Cloning of promoter region } \\
\mathrm{P}_{\text {pduA }} \text { in front of luxCDABE via } \\
\text { Sacl and } \mathrm{Kpnl} ; \mathrm{Cm}^{\mathrm{R}}\end{array}$ & This study \\
\hline $\begin{array}{l}\text { pUTs- } P_{f u c o}:: / u x \\
\left(\mathrm{Cm}^{R}\right)\end{array}$ & $\begin{array}{l}\text { Cloning of promoter region } \\
\mathrm{P}_{\text {fucO }} \text { in front of luxCDABE via } \\
\text { Sacl and Smal; } \mathrm{Cm}^{\mathrm{R}}\end{array}$ & This study \\
\hline $\begin{array}{l}\text { pUTs-P pduA ::gfp } \\
\left(\mathrm{Cm}^{\mathrm{R}}\right)\end{array}$ & $\begin{array}{l}\text { Cloning of promoter region } \\
\mathrm{P}_{p d u A} \text { in front of } g f p \text { via Notl; } \\
\mathrm{Cm}^{\mathrm{R}}\end{array}$ & This study \\
\hline pBR-pduC & $\begin{array}{l}\text { Complementing plasmid, Pvul } \\
\text { and Asel used for cloning of } \\
\text { pduC into pBR322; } \text { Tet }^{R}\end{array}$ & This study \\
\hline pBR-fucA & $\begin{array}{l}\text { Complementing plasmid, Pstl } \\
\text { and Ahdl used for cloning of } \\
\text { fucA; Tet }{ }^{R}\end{array}$ & This study \\
\hline
\end{tabular}

at $180 \mathrm{rpm}$. If appropriate, the following antibiotics were used: ampicillin $(100 \mu \mathrm{g} / \mathrm{ml})$, chloramphenicol $(20 \mu \mathrm{g} / \mathrm{ml})$, kanamycin $(50 \mu \mathrm{g} / \mathrm{ml})$, nalidixic acid $(20 \mu \mathrm{g} / \mathrm{ml})$, or tetracycline $(12 \mu \mathrm{g} / \mathrm{ml})$.

To test growth on single carbon sources, $S$. Typhimurium strain 14028 was cultivated in Vogel-Bonner no-carbon E medium (VB-NCE; $0.82 \mathrm{mM} \mathrm{MgSO}_{4}, 0.0574 \mathrm{mM} \mathrm{K} \mathrm{HPO}_{4}$, and $16.74 \mathrm{mM} \mathrm{NaNH}_{4} \mathrm{HPO}_{4}$ ) supplemented with trace elements (0.3 $\mathrm{mM} \mathrm{CaCl}_{2}, 0.1 \mathrm{mM} \mathrm{ZnSO}, 0.045 \mathrm{mM} \mathrm{FeSO}_{4}, 0.2 \mathrm{mM}$
$\mathrm{Na}_{2} \mathrm{Se}_{2} \mathrm{O}_{3}, 0.2 \mathrm{mM} \mathrm{Na}_{2} \mathrm{MoO}_{4}, 2 \mathrm{mM} \mathrm{MnSO}_{4}, 0.1 \mathrm{mM} \mathrm{CuSO}$, $3 \mathrm{mM} \mathrm{CoCl}_{2}$, and $0.1 \mathrm{mM} \mathrm{NiSO}$; Vogel and Bonner, 1956; Price-Carter et al., 2001). To enhance initial growth, $0.2 \%$ (w/v) yeast extract (VB-NCE-YE) was added. $40 \mathrm{mM} \mathrm{Na-tetrathionate}$ was supplemented for anaerobic or $200 \mathrm{nM}$ cyano-cobalamin for aerobic cultivation (Price-Carter et al., 2001). Unless otherwise stated, carbon sources were used in the following concentrations: $25 \mathrm{mM}$ 1,2-PD, $25 \mathrm{mM}$ L-fucose (fucose), and $27.8 \mathrm{mM}$ D-glucose (glucose). Liquid media were inoculated using a final dilution of LB-overnight cultures of 1:250. For anaerobic cultivation (without shaking), media without tetrathionate were stored in an anaerobic chamber (A35, DonWhitley, Shipley, $\mathrm{UK})$ in an atmosphere of $80 \% \mathrm{~N}_{2}, 10 \% \mathrm{CO}_{2}$, and $10 \% \mathrm{H}_{2}$ overnight, before tetrathionate was added. To monitor the optical density at wavelength $600 \mathrm{~nm}\left(\mathrm{OD}_{600}\right)$ of a bacterial culture and, if applicable, its bioluminescence in relative light units of luminescence at $\mathrm{OD}_{490}\left(\mathrm{RLU}_{490}\right)$, samples were transferred in triplicate into 96-well microtiter plates with $200 \mu \mathrm{l}$ of medium per well, and measured with the multilable plate reader Wallac Victor ${ }^{3}$ (Perkin Elmer, Waltham, MA, USA) as described previously (Kröger and Fuchs, 2009).

\section{General Molecular Techniques}

Standard protocols (Sambrook and Russell, 2001) or manufacturer's instructions were applied for manipulation and isolation of DNA and plasmids. For polymerase chain reaction (PCR) isolated DNA, plasmid DNA, cDNA, or single colonies dissolved in $\mathrm{H}_{2} \mathrm{O}$ served as templates. Taq polymerase (Schauer, 2010) was used with the following program: $95^{\circ} \mathrm{C}$ for $5 \mathrm{~min}$ and $35 \mathrm{cycles}$ at $95^{\circ} \mathrm{C}$ for $10 \mathrm{~s}$; annealing at temperatures chosen according to the primers for $30 \mathrm{~s}$; elongation periods at $72^{\circ} \mathrm{C}$ chosen according to amplicon size; and a final elongation step at $72^{\circ} \mathrm{C}$ for $8 \mathrm{~min}$. Primers for PCR were purchased from MWG-Biotech (Ebersberg, Germany). Amplification mixtures were loaded on agarose gels using GeneRuler ${ }^{\text {TM }}$ DNA ladder mix (Thermo Scientific, Braunschweig, Germany) as a size reference. E. coli strain S17.1 cells were used as the donor for conjugational transfer of pUTs vectors to $S$. Typhimurium (Simon et al., 1983).

\section{Microscopy}

Bacteria were investigated for green fluorescent protein (GFP) expression using an Olympus BX-51 fluorescence microscope (Olympus, Hamburg, Germany). Analysis was performed using the F-View Soft Imaging System and the software cell ${ }^{\mathrm{F}}$ at $1,000 \times$ magnification. Bacteria were concentrated after sampling by centrifugation and kept on ice until observation of aliquots using bright-field microscopy and the GFP fluorescence channel. To obtain three-dimensional pictures, an inverted confocal microscope (IX81, Olympus) was used at $400 \times$ magnification. Z-stacks were recorded and reconstructed with Volocity 6.0 software (Perkin Elmer).

\section{Construction of Mutants and Plasmids}

To generate kanamycin-insertion mutants and non-polar gene deletions, we applied the method established by Datsenko and Wanner (2000). Briefly, vector pKD46 encoding the $\lambda$ Red recombinase system was transferred into strain 14028 
by electroporation. Cells were then transformed with a PCR fragment harboring the kanamycin cassette and FRT sites amplified from pKD4 as well as extensions of $50 \mathrm{bp}$ representing the $3^{\prime}$ - and $5^{\prime}$-ends of the target gene. Residues of $18 \mathrm{bp}$ on the $5^{\prime}$ - and $36 \mathrm{bp}$ on the $3^{\prime}$-end of the gene were left to avoid damage to possible promoter structures (Link et al., 1997). Homologous recombination was confirmed by kanamycin selection. To circumvent possible illegitimate recombination effects, the kanamycin insertion was transferred to 14028 by phage transduction (Maloy, 1990) as follows: an overnight culture of 14028 harboring the kanamycin-resistance cassette was diluted 1:100 into LB-medium. At $\mathrm{OD}_{600}=0.2,5 \mathrm{ml}$ of the culture was transferred into a glass tube, and $5 \mu \mathrm{l}$ of a P22 suspension were added. The mixture was incubated for $6 \mathrm{~h}$ at $37^{\circ} \mathrm{C}$ without shaking. Then, $50 \mu \mathrm{l}$ chloroform was added, and the suspension was stored at $4^{\circ} \mathrm{C}$ for $2 \mathrm{~h}$. The cell debris was pelleted at 9,000 $\times g$ and $4^{\circ} \mathrm{C}$ for $10 \mathrm{~min}$. The supernatant was filter sterilized with a $0.2-\mu \mathrm{m}$ pore filter, and $200 \mu \mathrm{l}$ of an overnight culture of strain 14028 was mixed with $10 \mu \mathrm{l}$ of the phage lysate. After $1 \mathrm{~h}$ incubation at $37^{\circ} \mathrm{C}$ without shaking, the suspension was plated on selective agar-plates. Bacteria were cultivated on green indicator plates to isolate phage-free colonies. Vector pCP20 was used to eliminate the $\mathrm{Kan}^{\mathrm{R}}$-cassette (Datsenko and Wanner, 2000). Deletions were confirmed by PCR and DNA sequencing (GATC, Konstanz, Germany).

To complement gene deletions, the coding sequences of the genes were cloned into pBR322. Gene $p d u C$ without a promoter was ligated into the $P v u \mathrm{I} / A s e \mathrm{I}$ restricted plasmid, thus exploiting the B-lactamase (bla) promoter. For $\Delta f u c A$ complementation, the promoter region of $500 \mathrm{bp}$ upstream of $f u c A$ was amplified together along with the gene, and cloned into pBR322 via PstI/AhdI. Plasmids were verified by sequencing.

\section{Generation of Reporter Strains}

To generate chromosomal fusions of promoter regions to the promoterless reporter genes luxCDABE or $g f p$, fragments located $500 \mathrm{bp}$ upstream of the target genes $p d u A$ and $f u c O$ were amplified by PCR and cloned into the plasmids pUTs$l u x$ and pUTs-gfp (see Supplementary Table S1 for primers). The ligated plasmids were transformed into E. coli S17.1, and putative positive clones were selected on LB-agar with chloramphenicol $(20 \mu \mathrm{g} / \mathrm{ml})$ and identified by PCR. Conjugation was then performed to transfer the recombinant plasmids to $S$. Typhimurium. Transformants were selected on LB-agar supplemented with nalidixic acid and chloramphenicol, or on chloramphenicol-containing Brilliance Salmonella agar (Oxoid, Wesel, Germany). Successful integration of the plasmid into the genome of $S$. Typhimurium strains was confirmed by PCR.

\section{Isolation of DNA and RNA, and CDNA Synthesis}

To isolate bacterial genomic DNA, $1.5 \mathrm{ml}$ of an overnight culture were centrifuged. After resuspension of the bacterial pellet in $400 \mu \mathrm{l}$ lysis solution (100 mM Tris- $\mathrm{HCl} \mathrm{pH}$ 8.0, $5 \mathrm{mM}$ ETDA, and $200 \mathrm{mM} \mathrm{NaCl}), 100 \mu \mathrm{l}$ lysozyme $(10 \mathrm{mg} / \mathrm{ml})$ was added. The suspension was stored on ice for $15 \mathrm{~min}$ and incubated over night at $55^{\circ} \mathrm{C}$ after addition of $10 \mu \mathrm{l} 10 \%(\mathrm{w} / \mathrm{v})$ sodium dodecyl sulfate
(SDS) and $5 \mu \mathrm{l}$ proteinase $\mathrm{K}(10 \mathrm{mg} / \mathrm{ml})$. Then, $500 \mu \mathrm{l}$ 2-propanol was added, and the DNA was sedimented by centrifugation. The supernatant was discarded, and the DNA was washed with $70 \%$ (v/v) ethanol. After a further centrifugation step, the DNA pellet was air-dried and dissolved in $150 \mu \mathrm{H}_{2} \mathrm{O}$ and $1 \mu \mathrm{l}$ RNase $(10 \mathrm{mg} / \mathrm{ml})$.

For RNA isolation (Chomczynski and Sacchi, 1987), strain 14028 was grown in $50 \mathrm{ml} \mathrm{VB-NCE-YE} \mathrm{supplemented} \mathrm{with} \mathrm{either}$ glucose or 1,2-PD to an $\mathrm{OD}_{600}$ of 2.0. The bacteria were harvested in $50 \mathrm{ml}$ reaction tubes and centrifuged at $3,220 \times g$ at $4^{\circ} \mathrm{C}$ for $10 \mathrm{~min}$. The supernatant was discarded, and the pellet was dissolved in $1 \mathrm{ml}$ TRIZOL (Invitrogen, Karlsruhe, Germany) by gentle mixing. The TRIZOL/RNA solution was extracted with $400 \mu \mathrm{l}$ of chloroform, and the aqueous phase was mixed with $450 \mu \mathrm{l}$ of 2-propanol. After $30 \mathrm{~min}$ at room temperature (RT) and a further centrifugation step, the supernatant was removed, and the pellet was washed with ethanol and resuspended in 25 $\mu l$ RNase-free water ( $1 \mathrm{ml}$ diethylpyrocarbonate in $11 \mathrm{H}_{2} \mathrm{O}$ ). Forty micrograms of nucleic acids were then dissolved in $79 \mu \mathrm{l}$ of RNase-free water and incubated at $65^{\circ} \mathrm{C}$ for $5 \mathrm{~min}$. The RNA was kept on ice for $5 \mathrm{~min}$, and $10 \mu \mathrm{l}$ of $10 \times$ DNase buffer and $10 \mu \mathrm{l}$ of DNase $(1 \mathrm{U} / \mu \mathrm{l})$ were added. After incubation at $37^{\circ} \mathrm{C}$ for $75 \mathrm{~min}$, the sample was mixed with $100 \mu \mathrm{l}$ Roti-Aqua-P/C/I and centrifuged at $15^{\circ} \mathrm{C}$ for $12 \mathrm{~min}$ at $17,000 \times g$. The aqueous phase was transferred to a $1.5-\mathrm{ml}$ reaction tube. A 2.5 -fold volume of a 1:30 mixture of ethanol and $3 \mathrm{M} \mathrm{Na}$-acetate $(\mathrm{pH}$ 6.5) was added to the RNA sample. The tube was incubated overnight at $-20^{\circ} \mathrm{C}$ and then centrifuged at $17,000 \times g$ and $4^{\circ} \mathrm{C}$ for $30 \mathrm{~min}$. The pellet was washed with $70 \%(\mathrm{v} / \mathrm{v})$ ethanol and dissolved in $40 \mu \mathrm{l}$ RNase-free water. The RNA concentration and quality was determined with a NanoDrop-1000 (Thermo Scientific). The qSkript ${ }^{\mathrm{TM}} \mathrm{cDNA}$ SuperMix of Quanta biosciences (Gaithersburg, MD, USA) was then used for cDNA synthesis according to the manufacturer's instructions. The resulting cDNA sample was diluted 1:10 in $\mathrm{H}_{2} \mathrm{O}$ and used for PCR.

\section{RESULTS}

\section{The pdu Operon is Polycistronically Transcribed}

To investigate the transcription of the $p d u$ operon, promoters were predicted in silico using the BPROM (www.softberry.com) prediction tool, the nucleotide sequence of $S$. Typhimurium strain LT2 (NC_003197.1), and the 500-bp section upstream of the translational start site of each gene of the $p d u$ operon. Possible promoters with probability scores of $\geq 20$ were found in front of nearly all genes except $p d u C, p d u H, p d u N$, $p d u P$, pduS, and $p d u X$. Binding sites of transcription factors were not found within these predicted promoter sequences, with the exception of $\mathrm{P}_{p d u A}$ to which several transcription factors putatively bind.

To test whether the $p d u$ operon (Figure 1A) is transcribed as a single polycistronic mRNA from $\mathrm{P}_{p d u A}$ or as multiple mRNAs from different promoters, RNA was isolated from $S$. Typhimurium grown with 1,2-PD and used as a template for reverse transcriptase polymerase chain reaction (RT-PCR) with random oligonucleotides. The RNA was shown to be free of DNA. 


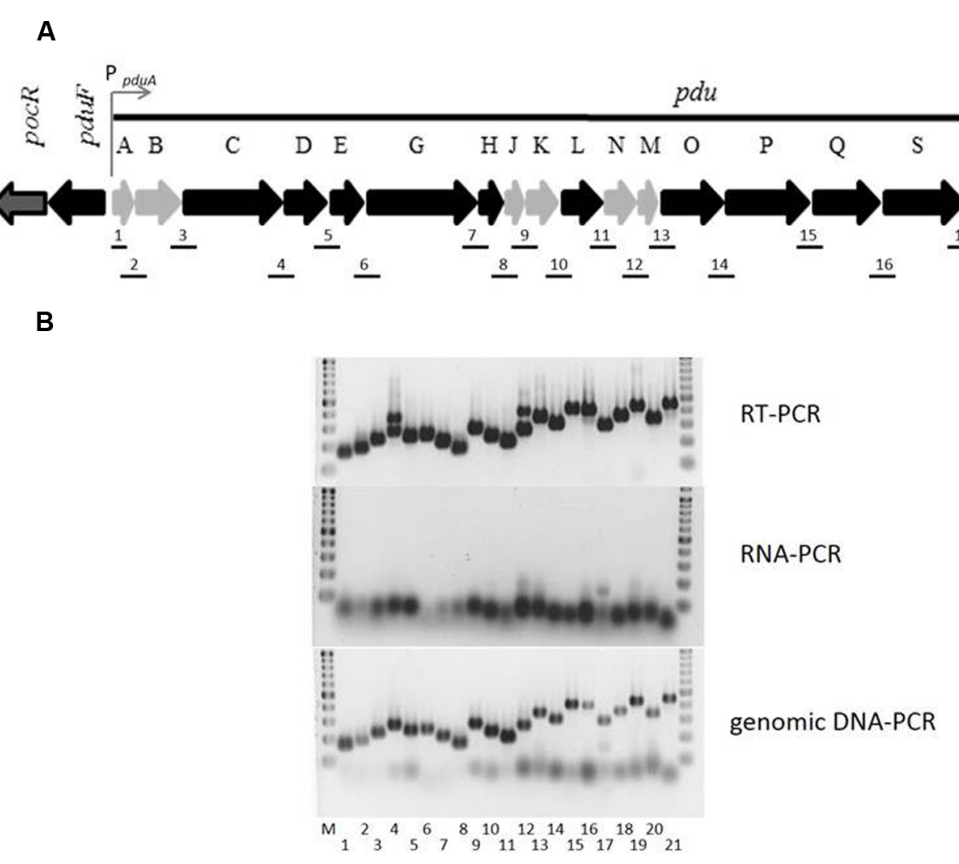

FIGURE 1 | Genomic organization and transcription of the pdu operon in Salmonella enterica serovar Typhimurium (S. Typhimurium) strain 14028. (A) The pdu genes coding for proteins with enzymatic function are colored in black, and genes-encoding proteins contributing to the formation of the microcompartment-like polyhedral body are shaded in gray. The promoter $\mathrm{P}_{p d u A}$ is indicated with an arrow upstream of pduA. (B) Transcription of the pdu operon. For RNA isolation, strain 14028 was grown aerobically in VB-NCE-YE medium supplemented with trace elements, cobalamin, and $50 \mathrm{mM} 1,2-\mathrm{PD}$ to an OD 600 of 2.0. An aliquot of $100 \mathrm{ng}$ of CDNA obtained by reverse transcription of RNA was used as a template for RT-PCR. Genomic DNA (100 ng) of strain 14028 served as a positive control, and total RNA (100 ng) as a negative control. Line numbers match the PCR product numbers in (A). GeneRuler ${ }^{\mathrm{TM}}$ DNA ladder mix (Thermo Scientific) was used as a marker (M). The resulting fragments were separated on $2 \%(\mathrm{~W} / \mathrm{v})$ agarose gels.

Amplicons spanning the intergenic regions between the $3^{\prime}$-end of the upstream and the $5^{\prime}$-end of the downstream adjacent $p d u$ genes were generated with all primer pairs using cDNA as a template, and the lengths of these amplicons corresponded to the PCR products obtained with genomic DNA as the template (Figure 1B). It can thus be concluded that the $p d u$ operon is transcribed as a single mRNA, confirming the single transcription start site of the $p d u$ operon (Chen et al., 1995).

\section{Pdu Gene Expression during Growth of S. Typhimurium with 1,2-PD}

Under anaerobic conditions, $S$. Typhimurium strain 14028 can be grown in VB-NCE-YE medium supplemented with 1,2$\mathrm{PD}$ and tetrathionate as an electron acceptor (Price-Carter et al., 2001). To investigate whether growth of $S$. Typhimurium indeed depends on the expression of the $p d u$ operon under these conditions, the gene $p d u C$, which encodes the large subunit of diol dehydratase PduC, the central enzyme in 1,2-PD degradation, was deleted. Growth of strain 14028 $\triangle p d u C$ with $1,2-\mathrm{PD}$ was severely attenuated under anaerobic conditions (Figure 2A), thus confirming the analysis of a $p d u C$ point mutation (Walter et al., 1997). The deletion was partially restored when the complementation plasmid pBR$p d u C$ was present in $14028 \Delta p d u C$. To demonstrate that this growth phenotype of $14028 \Delta p d u C$ is specific to a medium with 1,2-PD as carbon source, the strains were also grown anaerobically in the presence of glucose. No significant differences between the two growth curves were observed (Figure 2A). Growth of $S$. Typhimurium with 1,2-PD resulted in a lower cell density than growth with the better energy source glucose.

A stimulatory effect of 1,2-PD on the $p d u$ genes has been demonstrated by $\mathrm{Mu}$ d-lac transcriptional fusions (Rondon and Escalante-Semerena, 1992). For more detailed investigation, the expression of the $p d u$ operon was monitored during all growth phases using the reporter strain $14028 \mathrm{P}_{p d u A}:$ :lux, which was cultivated under the same growth conditions as described above. Bioluminescence $\left(\mathrm{RLU}_{490}\right)$ was recorded in parallel with $\mathrm{OD}_{600}$ (Figure 2B). As a control, the same strain was grown with glucose, and a maximal value of 2,000 RLU 490 was determined as background luminescence or leaky expression of the reporter. The transcriptional activity of $\mathrm{P}_{p d u A}$ reached a maximum of $2.53 \times 10^{6} \mathrm{RLU}_{490}$ in approximately the middle of the logarithmic growth phase, and then gradually decreased until the culture reached the stationary phase $8 \mathrm{~h}$ after inoculation.

\section{1,2-PD at $50 \mu M$ is Sufficient to Induce $\mathbf{P}_{p d u A}$, and Glucose Represses pdu Transcription}

To determine the minimal concentration of 1,2-PD required to induce gene expression from $\mathrm{P}_{p d u A}$, the reporter strain 


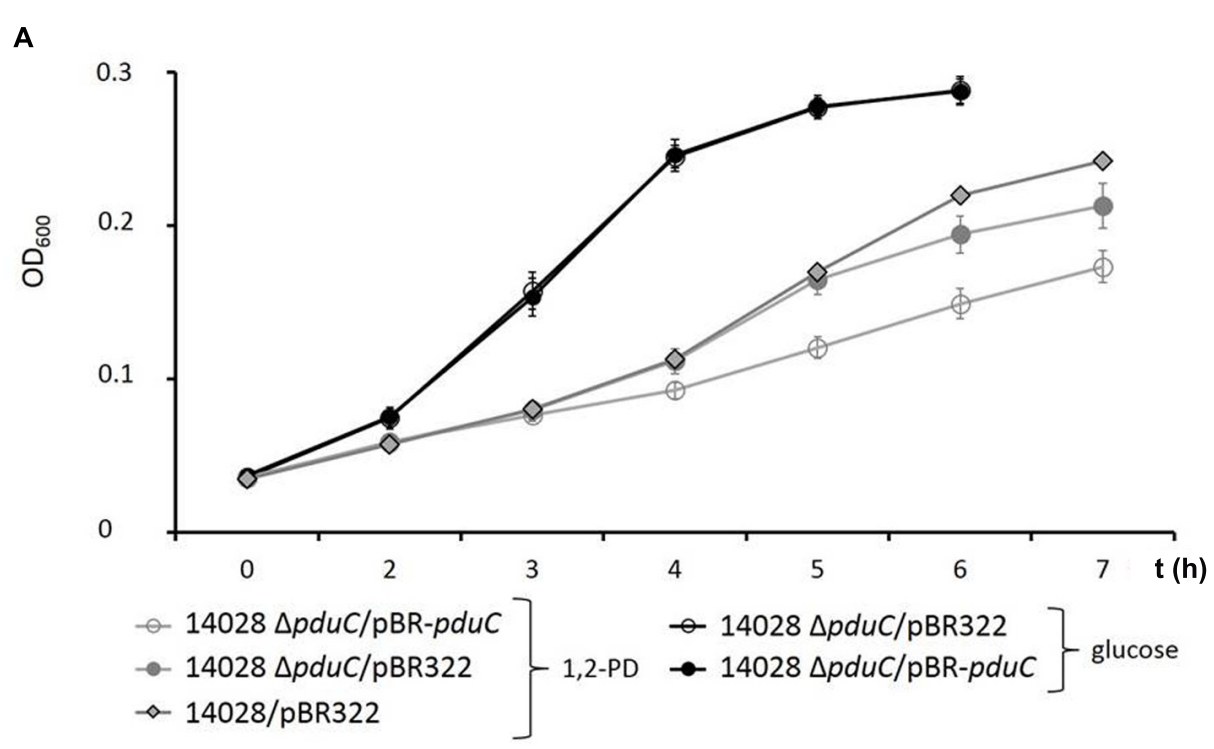

B

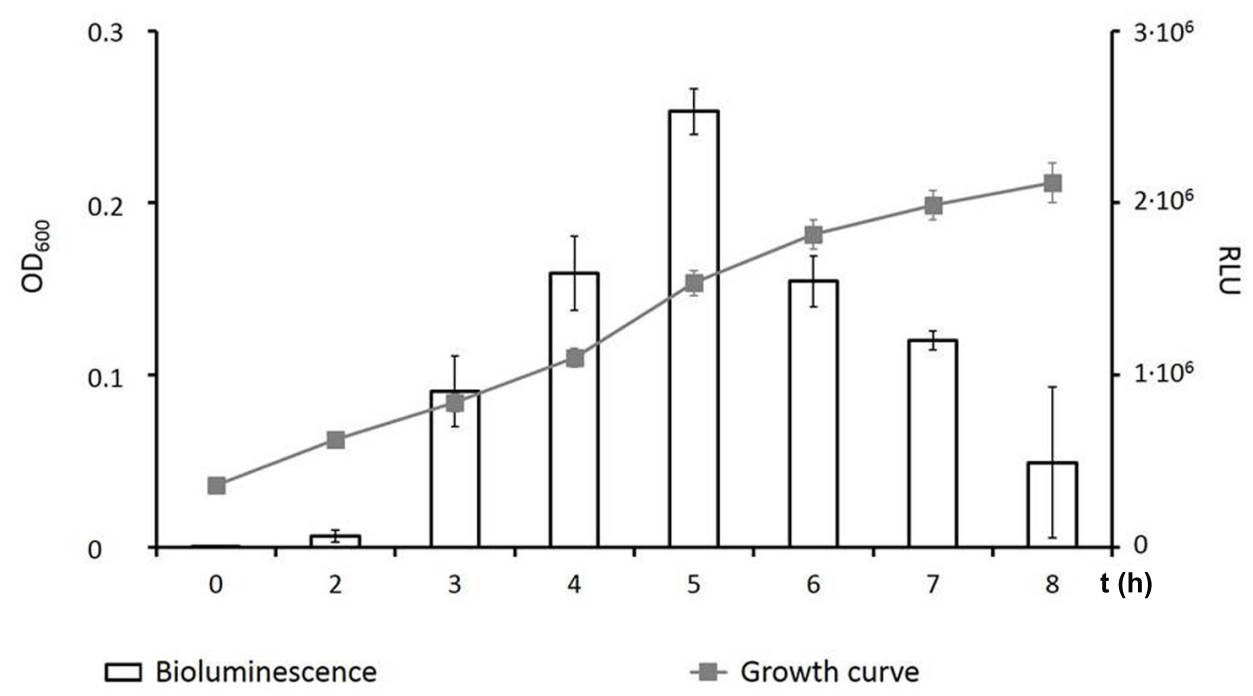

FIGURE 2 | Growth assays of strain 14028 with 1,2-PD. (A) Strains 14028/pBR322, $14028 \Delta p d u C / p B R 322$, and $14028 \Delta p d u C / p B R-p d u C$ were cultivated in 50 -ml cultures of VB-NCE-YE medium supplemented with trace elements, $40 \mathrm{mM}$ tetrathionate and $25 \mathrm{mM}$ 1,2-PD (gray traces), or $27.8 \mathrm{mM}$ glucose as control (black traces) in an oxygen-free environment. Samples were taken at the indicated time points and transferred to microtiter plates to monitor the $\mathrm{OD}_{600}$. (B) The transcriptional activity of $p d u A$ was determined using reporter strain $14028 \mathrm{P}_{p d u A}: / / 4 x . \mathrm{OD}_{600}$ and $\mathrm{RLU}_{490}$ were measured in parallel. Standard deviations of three independent experiments are indicated.

$14028 \mathrm{P}_{p d u A}:: g f p$ was grown anaerobically in VB-NCE-YE supplemented with trace elements, tetrathionate, and 1,2-PD in concentrations of $0.05 \mu \mathrm{M}, 0.01 \mu \mathrm{M}, 0.5 \mu \mathrm{M}, 1 \mu \mathrm{M}, 5 \mu \mathrm{M}$, $10 \mu \mathrm{M}, 50 \mu \mathrm{M}, 0.1 \mathrm{mM}, 0.5 \mathrm{mM}$, and $1 \mathrm{mM}$. As a negative control, $14028 \mathrm{P}_{p d u A}:: g f p$ was grown in medium supplemented with glucose. Overnight cultures of $14028 \mathrm{P}_{p d u A}: g f p$ were diluted 1:250 in the respective media and incubated at $37^{\circ} \mathrm{C}$ in the anaerobic chamber. Samples were taken every $30 \mathrm{~min}$ from time point 0 to $330 \mathrm{~min}$ and analyzed by fluorescence microscopy. Transcriptional activity of $\mathrm{P}_{p d u A}$ was observed at 1,2PD concentrations of $50 \mu \mathrm{M}$ and higher, but not at $10 \mu \mathrm{M}$ or lower (Figure 3A).

To investigate the possible catabolite repression of $\mathrm{P}_{p d u A}$, strain $14028 \mathrm{P}_{p d u A}:: g f p$ was anaerobically grown in VB-NCE-YE supplemented with tetrathionate, trace elements, and $1 \mathrm{mM} \mathrm{1,2-}$ $\mathrm{PD}$, and with increasing glucose concentrations of $1,5,10$, and $25 \mathrm{mM}$. Cells were then monitored as described in the preceding experiment. At equimolar concentrations of 1,2-PD and glucose 
A

0.5

0.1

0.05

0.01
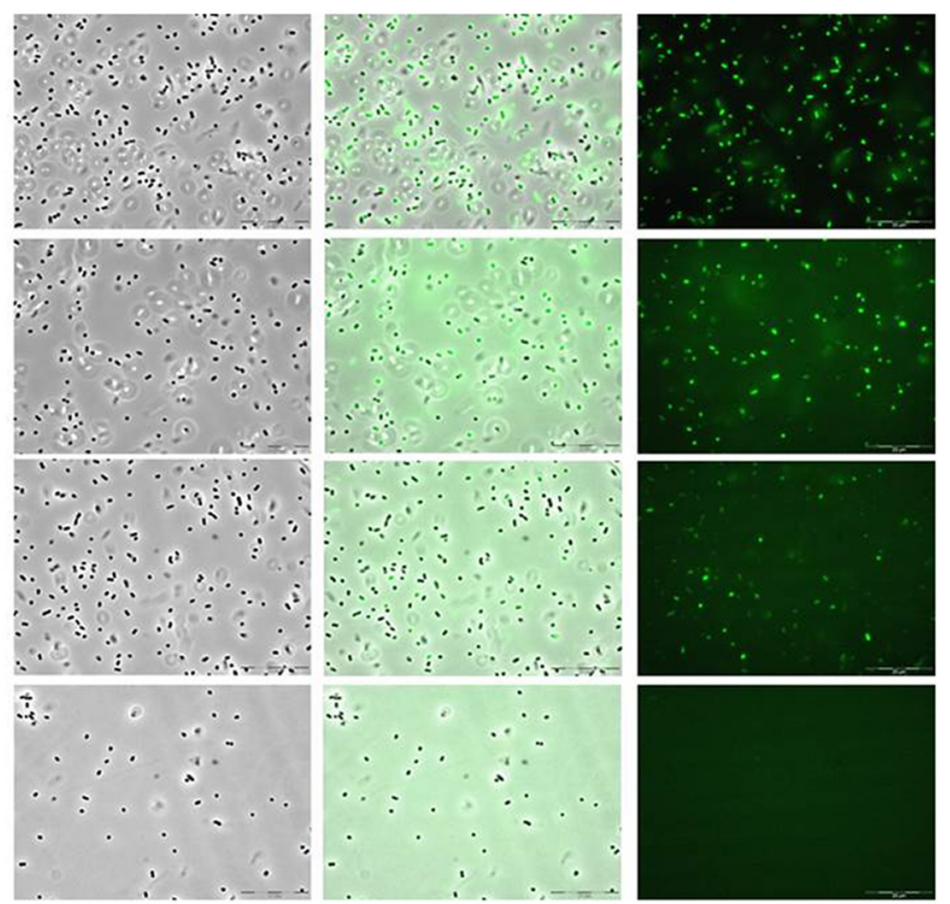

B

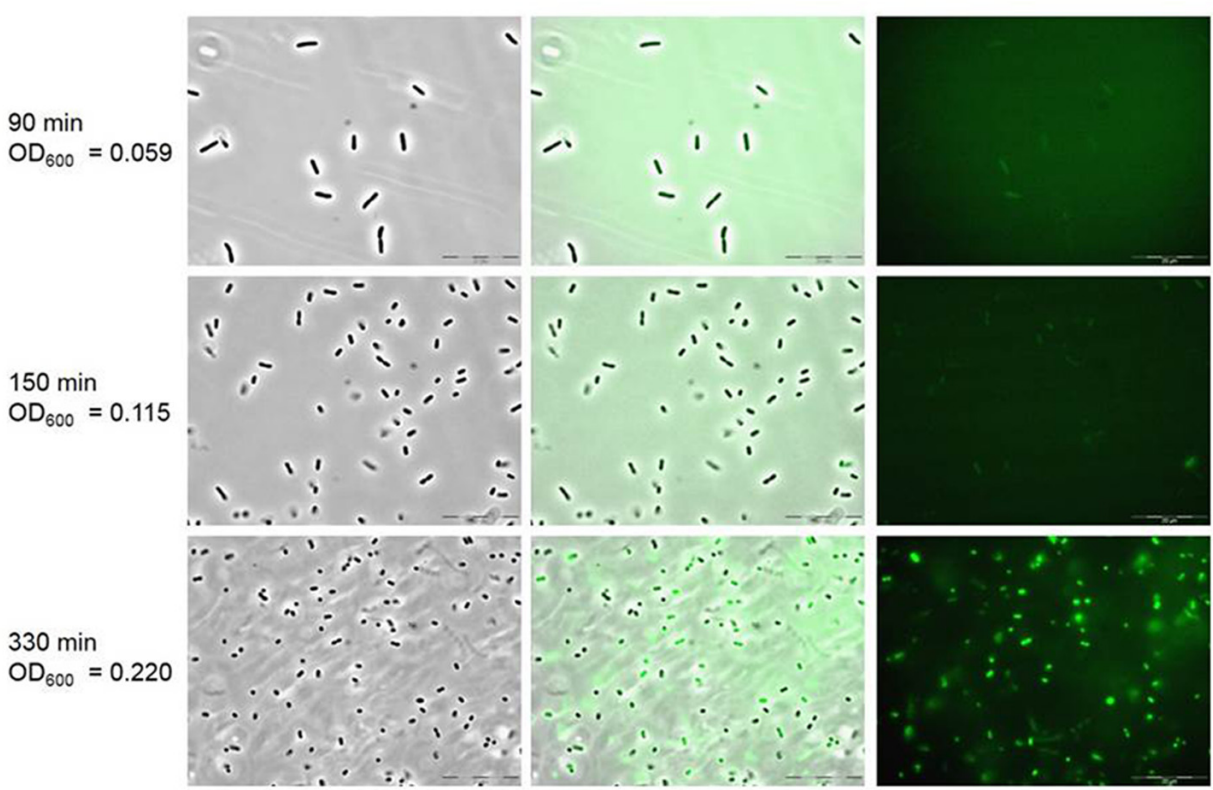

FIGURE 3 | Microscopic survey of strain $14028 P_{p d u A}:$ :gfp at varying concentrations of 1,2-PD and glucose. (A) Images were obtained 270 min post-inoculation in VB-NCE-YE medium supplemented with trace elements, tetrathionate, and 0.5, 0.1, 0.05, and 0.01 mM 1,2-PD as indicated on the left. The $\mathrm{OD}_{600}$ of the samples ranged from 0.143 to 0.151 . (B) Repressing influence of glucose concentrations on the induction of $\mathrm{P}_{\text {pduA }}$ by $1,2-\mathrm{PD}$. Cells were grown in the presence of $1 \mathrm{mM}$ 1,2-PD and $1 \mathrm{mM}$ glucose and monitored at the indicated cell densities and time points post-inoculation.

$(1 \mathrm{mM})$, no fluorescence was observed until late exponential phase $\left(\mathrm{OD}_{600}=0.220\right)$ due to glucose catabolization (Figure 3B).

These results confirm the suggestion that the promoters involved in 1,2-PD utilization are repressed by glucose (Roth et al., 1996). 


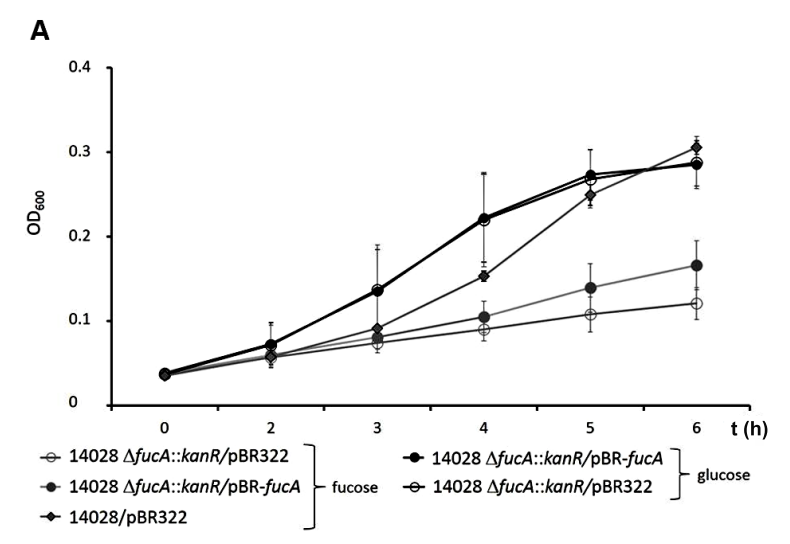

B

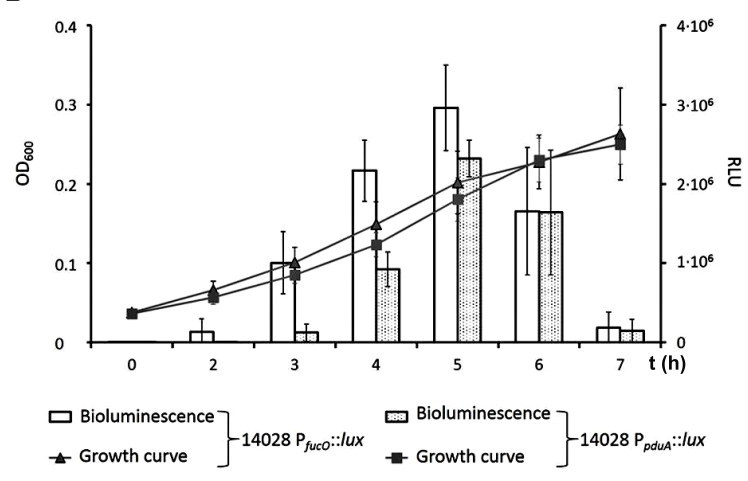

FIGURE 4 | Anaerobic growth of strain 14028 with fucose. (A) Growth curves of $14028 \mathrm{Nal}^{\mathrm{R}}, 14028 \Delta$ fucA::kan and $14028 \Delta$ fucA::kan/pBR-fucA with either $25 \mathrm{mM}$ fucose (in gray) or $27.8 \mathrm{mM}$ glucose (in black). Standard deviations of three independent experiments are indicated. (B) Transcriptional activity of $\mathrm{P}_{f u c O}$ and $\mathrm{P}_{\text {pduA }}$ was visualized by monitoring bioluminescence of $14028 \mathrm{P}_{\text {fuco }}:: / \mathrm{l}$ x and $14028 \mathrm{P}_{\text {pduA }}:: / \mathrm{l}$ x.

\section{FucA is Required for Proliferation of S. Typhimurium with Fucose}

Given that 1,2-PD is derived from the fermentative degradation of fucose, we investigated the anaerobic growth of $S$. Typhimurium strain 14028 in VB-NCE-YE medium containing fucose. Tetrathionate was also added to permit anaerobic respiration in the case of 1,2-PD formation and degradation. Growth of strain $14028 \Delta f u c A:: k a n R$, in which $f u c A$ was replaced by a kanamycin resistance cassette, was severely attenuated when compared to that of strain 14028 (Figure 4A). To complement the replacement of $f u c A$, mutant $14028 \triangle f u c A:: k a n R$ was equipped with pBR322-fucA. Although the plasmid did not completely restore the ability to use fucose, growth of the complemented mutant was improved from that of $14028 \Delta f u c A:: k a n R$. As a control, the mutant and the complemented strain were grown in VB-NCE-YE with glucose to exclude pleiotropic effects due to the mutation procedure. Possible biphasic growth due to sequential 1,2-PD utilization as suggested earlier (Obradors et al., 1988) was not observed.

To compare the expression pattern of the $p d u$ and $f u c$ operon, strains with luciferase fusions to the promoters of $p d u A$ and $f u c O\left(\mathrm{P}_{p d u A}\right.$ and $\left.\mathrm{P}_{f u c O}\right)$ were grown in VB-NCEYE medium supplemented with $25 \mathrm{mM}$ fucose, tetrathionate, and trace elements (Figure 4B). Luminescence of $\mathrm{P}_{f u c O} \mathrm{O:}: \mathrm{lux}$ was detected after $2 \mathrm{~h}$ and that of $\mathrm{P}_{p d u A}:: l u x$ at $3 \mathrm{~h}$ post-inoculation, suggesting a sequential induction of both operons according to their metabolic function. The reporter activity of both strains then increased until the late exponential phase of the culture and decreased after the culture reached the stationary phase. Notably, the transcriptional activity of $\mathrm{P}_{f u c O}$ was significantly higher than that of $\mathrm{P}_{p d u A}(p<0.05)$. Both operons were transcribed simultaneously during the exponential growth phase, but the transcription of the $p d u$ operon was slightly retarded when compared to that of the fuc genes. The data also showed that the 1,2-PD degrading factors were produced very early, even while those degrading fucose were still expressed, indicating that both substrates were simultaneously utilized.

\section{The fuc and pdu Operons are Highly Conserved among S. enterica Strains}

A comprehensive database search was performed with BLAST using all proteins encoded by the fuc and $p d u$ operon of S. Typhimurium strain LT2 (NC_003197) as queries. Proteins were considered to be absent from the respective serovar in the event of a query coverage below $60 \%$ and an identity score below $90 \%$. Homologs of proteins encoded by the $p d u$ and the $f u c$ operon of strain LT2 were identified in all 83 investigated serovars of $S$. enterica ssp. enterica investigated here, with the exceptions of serovar Litchfield and Stanleyville for which, however, only a shotgun sequence is available (Supplementary Table S2). Homologs of both pathways were also found in the S. enterica subspecies salamae, indica, diarizonae, arizonae, and houtenae. These results indicate that the $p d u$ and $f u c$ operons are highly conserved and present in nearly all Salmonella strains sequenced thus far.

\section{DISCUSSION}

When enteropathogens enter the gastrointestinal tract, they encounter nutrient competition with the host and the commensal microbiota. This nutrient limitation may be overcome by specific metabolic adaptations that contribute to proliferation within distinct host compartments. The mucus layer is a potential source of nutrients for pathogens that colonize and eventually penetrate the gut epithelium. The mucus is composed of mucin oligosaccharides, which are characterized by a large variety of carbohydrate side-chains that also contain rhamnose and fucose.

As revealed in the present study by database querying, the $p d u$ and $f u c$ operons are highly conserved and ubiquitously present in S. enterica strains, indicating that their gene products play a role in the metabolic adaptation of salmonellae to their environments. This inference is supported by the observation that compounds of the 1,2-PD utilization pathway are produced in high amounts when $S$. Typhimurium is grown under in vivomimicking conditions and in murine macrophages (Adkins et al., 2006; Shi et al., 2006; Sonck et al., 2009). 1,2-PD is obtained by the degradation of rhamnose and fucose, two sugars that 
are common constituents of glycoconjugates not only of the gut mucus, but also of plant cell walls. In line with this observation, a transcriptome of $S$. Typhimurium strain SL1344 showed a marked upregulation of its fuc, $p d u, c o b / c b i$, and ethanolamine utilization (eut) genes when the pathogen colonized lettuce and cilantro by coinfection with a plant pathogen (Goudeau et al., 2013). Interestingly, such a transcriptional activation of $p d u$ genes has also been observed for Listeria monocytogenes in the intestines of mice (Toledo-Arana et al., 2009). The gut pathogen Campylobacter jejuni has been shown to use L-fucose, which is probably derived from mucin, during colonization in a piglet model (Stahl et al., 2011).

Taken together, we hypothesize that the ability to degrade fucose and anaerobically respire 1,2-PD, probably using tetrathionate as a terminal electron acceptor, provides an advantage to $S$. Typhimurium during competition

\section{REFERENCES}

Abu Kwaik, Y., and Bumann, D. (2013). Microbial quest for food in vivo: 'nutritional virulence' as an emerging paradigm. Cell Microbiol. 15, 882-890. doi: $10.1111 / \mathrm{cmi} .12138$

Adkins, J. N., Mottaz, H. M., Norbeck, A. D., Gustin, J. K., Rue, J., Clauss, T. R., et al. (2006). Analysis of the Salmonella typhimurium proteome through environmental response toward infectious conditions. Mol. Cell. Proteomics 5, 1450-1461. doi: 10.1074/mcp.M600139-MCP200

Ailion, M., and Roth, J. R. (1997). Repression of the cob operon of Salmonella typhimurium by adenosylcobalamin is influenced by mutations in the pdu operon. J. Bacteriol. 179, 6084-6091.

Badia, J., Ros, J., and Aguilar, J. (1985). Fermentation mechanism of fucose and rhamnose in Salmonella typhimurium and Klebsiella pneumoniae. J. Bacteriol. 161, 435-437.

Bobik, T. A., Ailion, M., and Roth, J. R. (1992). A single regulatory gene integrates control of vitamin B12 synthesis and propanediol degradation. J. Bacteriol. 174, 2253-2266.

Bobik, T. A., Havemann, G. D., Busch, R. J., Williams, D. S., and Aldrich, H. C. (1999). The propanediol utilization (pdu) operon of Salmonella enterica serovar Typhimurium LT2 includes genes necessary for formation of polyhedral organelles involved in coenzyme B12-dependent 1, 2-propanediol degradation. J. Bacteriol. 181, 5967-5975.

Bobik, T. A., Xu, Y., Jeter, R. M., Otto, K. E., and Roth, J. R. (1997). Propanediol utilization genes (pdu) of Salmonella typhimurium: three genes for the propanediol dehydratase. J. Bacteriol. 179, 6633-6639.

Bolivar, F., Rodriguez, R. L., Greene, P. J., Betlach, M. C., Heyneker, H. L., Boyer, H. W., et al. (1977). Construction and characterization of new cloning vehicles. II. A multipurpose cloning system. Gene 2, 95-113.

Carnell, S. C., Bowen, A., Morgan, E., Maskell, D. J., Wallis, T. S., and Stevens, M. P. (2007). Role in virulence and protective efficacy in pigs of Salmonella enterica serovar Typhimurium secreted components identified by signaturetagged mutagenesis. Microbiology 153, 1940-1952. doi: 10.1099/mic.0.2006/00 6726-0

Centres for Disease Control and Prevention (2013). An Atlas of Salmonella in the United States, 1968-2011: Laboratory-Based Enteric Disease Surveillance. Atlanta, GA: US Department of Health and Human Services, Centers for Disease Control and Prevention (CDC).

Chaudhuri, R. R., Morgan, E., Peters, S. E., Pleasance, S. J., Hudson, D. L., Davies, H. M., et al. (2013). Comprehensive assignment of roles for Salmonella typhimurium genes in intestinal colonization of foodproducing animals. PLoS Genet. 9:e1003456. doi: 10.1371/journal.pgen.10 03456 with commensal bacteria to colonize the intestinal mucus layer.

\section{ACKNOWLEDGMENTS}

We thank Angela Felsl for her technical assistance. The Deutsche Forschungsgemeinschaft is gratefully acknowledged for a grant to LS in the Research Training Group (Graduiertenkolleg, GRK) 1482 "Interface functions of the intestine between luminal factors and host signals."

\section{SUPPLEMENTARY MATERIAL}

The Supplementary Material for this article can be found online at: http://journal.frontiersin.org/article/10.3389/fmicb. 2015.01116

Chaudhuri, R. R., Peters, S. E., Pleasance, S. J., Northen, H., Willers, C., Paterson, G. K., et al. (2009). Comprehensive identification of Salmonella enterica serovar Typhimurium genes required for infection of BALB/c mice. PLoS Pathog 5:e1000529. doi: 10.1371/journal.ppat.10 00529

Chen, P., Ailion, M., Bobik, T., Stormo, G., and Roth, J. (1995). Five promoters integrate control of the cob/pdu regulon in Salmonella typhimurium. J. Bacteriol. 177, 5401-5410.

Chen, P., Andersson, D. I., and Roth, J. R. (1994). The control region of the pdu/cob regulon in Salmonella typhimurium. J. Bacteriol. 176, 5474-5482.

Chomczynski, P., and Sacchi, N. (1987). Single-step method of RNA isolation by acid guanidinium thiocyanate-phenol-chloroform extraction. Anal. Biochem. 162, 156-159. doi: 10.1006/abio.1987.9999

Cocks, G. T., Aguilar, T., and Lin, E. C. (1974). Evolution of L-1, 2-propanediol catabolism in Escherichia coli by recruitment of enzymes for L-fucose and L-lactate metabolism. J. Bacteriol. 118, 83-88.

Conner, C. P., Heithoff, D. M., Julio, S. M., Sinsheimer, R. L., and Mahan, M. J. (1998). Differential patterns of acquired virulence genes distinguish Salmonella strains. Proc. Natl. Acad. Sci. U.S.A. 95, 4641-4645. doi: 10.1073/pnas.95.8. 4641

Daniel, R., Bobik, T. A., and Gottschalk, G. (1998). Biochemistry of coenzyme B12-dependent glycerol and diol dehydratases and organization of the encoding genes. FEMS Microbiol. Rev. 22, 553-566. doi: 10.1111/j.15746976.1998.tb00387.x

Datsenko, K. A., and Wanner, B. L. (2000). One-step inactivation of chromosomal genes in Escherichia coli K-12 using PCR products. Proc. Natl. Acad. Sci. U.S.A. 97, 6640-6645. doi: 10.1073/pnas.120163297

Deatherage Kaiser, B. L., Li, J., Sanford, J. A., Kim, Y. M., Kronewitter, S. R., Jones, M. B., et al. (2013). A multi-omic view of host-pathogencommensal interplay in -mediated intestinal infection. PLoS ONE 8:e67155. doi: 10.1371/journal.pone.0067155

European Centre for Disease Prevention and Control (2014). The european union summary report on trends and sources of zoonoses, zoonotic agents and food-borne outbreaks in 2012. EFSA J. 12:3547.

Fuchs, T. M., Eisenreich, W., Heesemann, J., and Goebel, W. (2012). Metabolic adaptation of human pathogenic and related nonpathogenic bacteria to extra- and intracellular habitats. FEMS Microbiol. Rev. 36, 435-462. doi: 10.1111/j.1574-6976.2011.00301.x

Galan, J. E., and Ginocchio, C. (1994). The molecular genetic bases of Salmonella entry into mammalian cells. Biochem. Soc. Trans. 22, 301-306. doi: 10.1042/bst0220301

Gaston, L. W., and Stadtman, E. R. (1963). Fermentation of ethylene glycol by Clostridium glycolicum, sp. n. J. Bacteriol. 85, 356-362. 
Goudeau, D. M., Parker, C. T., Zhou, Y., Sela, S., Kroupitski, Y., and Brandl, M. T. (2013). The Salmonella transcriptome in lettuce and cilantro soft rot reveals a niche overlap with the animal host intestine. Appl. Environ. Microbiol. 79, 250-262. doi: 10.1128/AEM.02290-12

Gutnick, D., Calvo, J. M., Klopotowski, T., and Ames, B. N. (1969). Compounds which serve as the sole source of carbon or nitrogen for Salmonella typhimurium LT-2. J. Bacteriol. 100, 215-219.

Heithoff, D. M., Conner, C. P., Hentschel, U., Govantes, F., Hanna, P. C., and Mahan, M. J. (1999). Coordinate intracellular expression of Salmonella genes induced during infection. J. Bacteriol. 181, 799-807.

Jeter, R. M. (1990). Cobalamin-dependent 1,2-propanediol utilization by Salmonella typhimurium. J. Gen. Microbiol. 136, 887-896. doi: 10.1099/00221287-136-5-887

Keeney, K. M., and Finlay, B. B. (2013). Microbiology: EHEC downregulates virulence in response to intestinal fucose. Curr. Biol. 23, R108-R110. doi: 10.1016/j.cub.2012.12.027

Klumpp, J., and Fuchs, T. M. (2007). Identification of novel genes in genomic islands that contribute to Salmonella typhimurium replication in macrophages. Microbiology 153, 1207-1220. doi: 10.1099/mic.0.\%202006/00 4747-0

Koch-Institut, R. (2014). Infektionsepidemiologisches Jahrbuch Meldepflichtiger Krankheiten für 2013. Berlin: Robert Koch-Institut.

Kröger, C., and Fuchs, T. M. (2009). Characterization of the myo-inositol utilization island of Salmonella enterica serovar Typhimurium. J. Bacteriol. 191, 545-554. doi: 10.1128/JB.01253-08

Kröger, C., Srikumar, S., Ellwart, J., and Fuchs, T. M. (2011). Bistability in myoinositol utilization by Salmonella enterica serovar Typhimurium. J. Bacteriol. 193, 1427-1435. doi: 10.1128/JB.00043-10

Lawley, T. D., Chan, K., Thompson, L. J., Kim, C. C., Govoni, G. R., and Monack, D. M. (2006). Genome-wide screen for Salmonella genes required for long-term systemic infection of the mouse. PLoS Pathog 2:e11. doi: 10.1371/journal.ppat.0020011

Link, A. J., Phillips, D., and Church, G. M. (1997). Methods for generating precise deletions and insertions in the genome of wild-type Escherichia coli: application to open reading frame characterization. J. Bacteriol. 179, 6228-6237.

Majowicz, S. E., Musto, J., Scallan, E., Angulo, F. J., Kirk, M., O’brien, S. J., et al. (2010). The global burden of nontyphoidal Salmonella gastroenteritis. Clin. Infect. Dis. 50, 882-889. doi: 10.1086/650733

Maloy, S. R. (1990). Experimental Techniques in Bacterial Genetics. Boston, MA: Jones and Bartlett Publishers, Inc.

Miller, W. G., and Lindow, S. E. (1997). An improved GFP cloning cassette designed for prokaryotic transcriptional fusions. Gene 191, 149-153. doi: 10.1016/S0378-1119(97)00051-6

Muraoka, W. T., and Zhang, Q. (2011). Phenotypic and genotypic evidence for L-fucose utilization by Campylobacter jejuni. J. Bacteriol. 193, 1065-1075. doi: 10.1128/JB.01252-10

Ng, K. M., Ferreyra, J. A., Higginbottom, S. K., Lynch, J. B., Kashyap, P. C., Gopinath, S., et al. (2013). Microbiota-liberated host sugars facilitate post-antibiotic expansion of enteric pathogens. Nature 502, 96-99. doi: 10.1038 /nature 12503

Obradors, N., Badia, J., Baldoma, L., and Aguilar, J. (1988). Anaerobic metabolism of the L-rhamnose fermentation product 1,2-propanediol in Salmonella typhimurium. J. Bacteriol. 170, 2159-2162.

Ochman, H., Soncini, F. C., Solomon, F., and Groisman, E. A. (1996). Identification of a pathogenicity island required for Salmonella survival in host cells. Proc. Natl. Acad. Sci. U.S.A. 93, 7800-7804. doi: 10.1073/pnas.93.15.7800

Price-Carter, M., Tingey, J., Bobik, T. A., and Roth, J. R. (2001). The alternative electron acceptor tetrathionate supports B12-dependent anaerobic growth of Salmonella enterica serovar Typhimurium on ethanolamine or 1,2propanediol. J. Bacteriol. 183, 2463-2475. doi: 10.1128/JB.183.8.2463-2475. 2001

Rondon, M. R., and Escalante-Semerena, J. C. (1992). The poc locus is required for 1,2-propanediol-dependent transcription of the cobalamin biosynthetic (cob) and propanediol utilization (pdu) genes of Salmonella typhimurium. J. Bacteriol. 174, 2267-2272.

Rondon, M. R., and Escalante-Semerena, J. C. (1996). In vitro analysis of the interactions between the PocR regulatory protein and the promoter region of the cobalamin biosynthetic (cob) operon of Salmonella typhimurium LT2. J. Bacteriol. 178, 2196-2203.

Roth, J. R., Lawrence, J. G., and Bobik, T. A. (1996). Cobalamin (coenzyme B12): synthesis and biological significance. Annu. Rev. Microbiol. 50, 137-181. doi: 10.1146/annurev.micro.50.1.137

Rothhardt, J. E., Kröger, C., Broadley, S. P., and Fuchs, T. M. (2014). The orphan regulator ReiD of Salmonella enterica is essential for myoinositol utilization. Mol. Microbiol. 94, 700-712. doi: 10.1111/mmi. 12788

Sambrook, J., and Russell, D. W. (2001). Molecular Cloning: A Laboratory Manual. New York, NY: Cold Spring Harbor Laboratory.

Sampson, E. M., and Bobik, T. A. (2008). Microcompartments for B12-dependent 1,2-propanediol degradation provide protection from DNA and cellular damage by a reactive metabolic intermediate. J. Bacteriol. 190, 2966-2971. doi: 10.1128/JB.01925-07

Schauer, K. (2010). Identifizierung und Charakterisierung Metabolischer und Struktureller Targets für Antimikrobielle Substanzen in Listeria Monocytogenes. Munich: Technische Universität München.

Shi, L., Adkins, J. N., Coleman, J. R., Schepmoes, A. A., Dohnkova, A., Mottaz, H. M., et al. (2006). Proteomic analysis of Salmonella enterica serovar Typhimurium isolated from RAW 264.7 macrophages: identification of a novel protein that contributes to the replication of serovar typhimurium inside macrophages. J. Biol. Chem. 281, 29131-29140. doi: 10.1074/jbc.M6046 40200

Simon, R., Priefer, U., and Pühler, A. (1983). A broad host range mobilization system for in vivo genetic engineering: transposon mutagenesis in Gram negative bacteria. Nat. Biotechnol. 1, 784-791. doi: 10.1038/nbt1183-784

Sonck, K. A., Kint, G., Schoofs, G., Vander Wauven, C., Vanderleyden, J., and De Keersmaecker, S. C. (2009). The proteome of Salmonella Typhimurium grown under in vivo-mimicking conditions. Proteomics 9, 565-579. doi: 10.1002/pmic. 200700476

Srikumar, S., and Fuchs, T. M. (2011). Ethanolamine utilization contributes to proliferation of Salmonella enterica serovar Typhimurium in food and in nematodes. Appl. Environ. Microbiol. 77, 281-290. doi: 10.1128/AEM.0 1403-10

Stahl, M., Friis, L. M., Nothaft, H., Liu, X., Li, J., Szymanski, C. M., et al. (2011). L-fucose utilization provides Campylobacter jejuni with a competitive advantage. Proc. Natl. Acad. Sci. U.S.A. 108, 7194-7199. doi: $10.1073 /$ pnas. 1014125108

Staib, L., and Fuchs, T. M. (2014). From food to cell: nutrient exploitation strategies of enteropathogens. Microbiology 160, 1020-1039. doi: 10.1099/mic.0.078105-0

Starke, M., Richter, M., and Fuchs, T. M. (2013). The insecticidal toxin genes of Yersinia enterocolitica are activated by the thermolabile LTTRlike regulator TcaR2 at low temperatures. Mol. Microbiol. 89, 596-611. doi: 10.1111/mmi. 12296

Stojiljkovic, I., Baumler, A. J., and Heffron, F. (1995). Ethanolamine utilization in Salmonella typhimurium: nucleotide sequence, protein expression, and mutational analysis of the cchA cchB eutE eutJ eutG eutH gene cluster. J. Bacteriol. 177, 1357-1366.

Thiennimitr, P., Winter, S. E., Winter, M. G., Xavier, M. N., Tolstikov, V., Huseby, D. L., et al. (2011). Intestinal inflammation allows Salmonella to use ethanolamine to compete with the microbiota. Proc. Natl. Acad. Sci. U.S.A. 108, 17480-17485. doi: 10.1073/pnas.11078 57108

Toledo-Arana, A., Dussurget, O., Nikitas, G., Sesto, N., Guet-Revillet, H., Balestrino, D., et al. (2009). The Listeria transcriptional landscape from saprophytism to virulence. Nature 459, 950-956. doi: 10.1038/nature0 8080

Toraya, T., Honda, S., and Fukui, S. (1979). Fermentation of 1,2propanediol with 1,2-ethanediol by some genera of Enterobacteriaceae, involving coenzyme B12-dependent diol dehydratase. J. Bacteriol. 139, 39-47.

Tsolis, R. M., Adams, L. G., Ficht, T. A., and Baumler, A. J. (1999). Contribution of Salmonella typhimurium virulence factors to diarrheal disease in calves. Infect. Immun. 67, 4879-4885.

Vogel, H. J., and Bonner, D. M. (1956). Acetylornithinase of Escherichia coli: partial purification and some properties. J. Biol. Chem. 218, 97-106. 
Walter, D., Ailion, M., and Roth, J. (1997). Genetic characterization of the pdu operon: use of 1,2-propanediol in Salmonella typhimurium. J. Bacteriol. 179, 1013-1022.

Winter, S. E., Thiennimitr, P., Winter, M. G., Butler, B. P., Huseby, D. L., Crawford, R. W., et al. (2010). Gut inflammation provides a respiratory electron acceptor for Salmonella. Nature 467, 426-429. doi: 10.1038/nature09415

Zhang, S., Kingsley, R. A., Santos, R. L., Andrews-Polymenis, H., Raffatellu, M., Figueiredo, J., et al. (2003). Molecular pathogenesis of Salmonella enterica serotype Typhimurium-induced diarrhea. Infect. Immun. 71, 1-12. doi: 10.1128/IAI.71.1.1-12.2003
Conflict of Interest Statement: The authors declare that the research was conducted in the absence of any commercial or financial relationships that could be construed as a potential conflict of interest.

Copyright (c) 2015 Staib and Fuchs. This is an open-access article distributed under the terms of the Creative Commons Attribution License (CC BY). The use, distribution or reproduction in other forums is permitted, provided the original author(s) or licensor are credited and that the original publication in this journal is cited, in accordance with accepted academic practice. No use, distribution or reproduction is permitted which does not comply with these terms. 